\title{
PEMANFAATAN KERJA SAMA INDONESIA-JEPANG ECONOMIC PARTNERSHIP AGREEMENT (IJEPA) DAN INDONESIA - PAKISTAN PREFERENTIAL TRADE AGREEMENT (IPPTA)
}

\section{Utilization of Indonesia-Japan Economic Partenrship Agreement (IJEPA) and Indonesia - Pakistan Preferential Trade Agreement (IPPTA)}

\author{
Endah Ayu Ningsih'1, Telisa Aulia Falianty ${ }^{2}$, Fitri Tri Budiarti ${ }^{1}$ \\ ${ }_{1}^{1}$ Pusat Pengkajian Kerja sama Perdagangan Internasional, Kementerian Perdagangan-RI, \\ JI.M.I. Ridwan Rais No.5 Jakarta, 10110, Indonesia \\ ${ }^{2}$ Departemen Ilmu Ekonomi, Fakultas Ekonomi dan Bisnis, Universitas Indonesia, Indonesia \\ Email: ayuningsih.endah@gmail.com
}

Naskah diterima: 10/02/2018; Naskah direvisi: 26/06/2018; Disetujui diterbitkan: 11/12/2018 Dipublikasikan online: 31/12/2018

\begin{abstract}
Abstrak
Penelitian ini mengevaluasi tingkat pemanfaatan Indonesia-Japan Economic Partnership Agreement (IJEPA) dan Indonesia-Pakistan Preferential Trade Agreement (IPPTA) dalam ekspor dan impor Indonesia ke Jepang dan Pakistan. Tingkat pemanfaatan FTA untuk ekspor menggunakan rasio nilai perdagangan yang termuat dalam Surat Keterangan Asal (SKA) terhadap nilai ekspor ke negara mitra. Sedangkan tingkat pemanfaatan impor menggunakan rasio nilai impor produk yang memenuhi syarat terhadap total impor Indonesia dari negara mitra. Studi ini menemukan bahwa pemanfaatan IJEPA (2012-2016) cenderung menurun. Pada tahun 2016 tingkat pemanfaatan ekspor sebesar 47,2\%. Sementara pemanfaatan IPPTA untuk ekspor ke Pakistan mengalami peningkatan yang signifikan sejak diimplementasi tahun 2013 dengan tingkat pemanfaatan ekspor sebesar 72,0\% pada tahun 2016. Di sisi impor pemanfaatan IJEPA mencapai $67,7 \%$ sementara IPPTA hanya 18,8\% (2016). Pemanfaatan impor IJEPA dan IPPTA relatif stagnan, jumlah perusahaan yang menggunakan SKA IJEPA sudah pada level jenuh, sementara pengguna SKA IPPTA masih tumbuh $18,2 \%$ per tahun. Bentuk PTA lebih memberikan dampak positif bagi peningkatan ekspor Indonesia ke negara mitra dibandingkan FTA yang komprehensif. Kebijakan melakukan FTA dalam bentuk Economic Partnership perlu disertai dengan kerja sama yang menjamin peningkatan perdagangan yang seimbang antar negara anggota.
\end{abstract}

Kata Kunci: Utilisasi FTA, IJEPA, IP-PTA

\begin{abstract}
This study aims to address the utilization level of The Indonesia-Japan Economic Partnership Agreement (IJEPA) and Indonesia-Pakistan Preferential Trade Agreement (IPPTA). The level of FTA utilization for exports was measured by the ratio of trade value recorded in the Certificate of Origin (CoO) to Indonesia's export value to the related country. While the level of utilization of imports was defined by the ratio of the import value of eligible products to Indonesia's total imports from the related country. The study found IJEPA's utilization during 2012-2016 tended to decrease. In 2016, the level of utilization was about 47.2\%. While IPPTA utilization for exports to Pakistan experienced a significant increase since it was implemented in 2013 with a rate of export utilization was $72.0 \%$ in 2016. On the import side, the level of utilization under IJEPA reached $67.7 \%$ while IPPTA was only $18.8 \%$ at the same period. In terms of the imports utilization level of both IJEPA and IPPTA, it was relatively stagnant, while the number of companies utilize IJEPA's CoO was saturated. In contrast, IPPTA's CoO users still grew at $18.2 \%$ per year. This study concluded PTA provides more positive impact on increasing Indonesia's exports to related countries than comprehensive FTAs. Thus, establishing an FTA in the form of an Economic Partnership needs to be followed with the cooperation that guarantees trade balance within the parties.
\end{abstract}


Keywords: FTA Utilization, IJEPA, IP-PTA

JEL Classification: F12, F13, F15

PENDAHULUAN

Free Trade Agreement (FTA) merupakan skema penurunan tarif di mana negara-negara anggota memiliki hak istimewa untuk memperoleh tingkat tarif kurang dari tingkat tarif Most Favored Nation (MFN) ketika melakukan ekspor ke mitra FTA mereka. Namun dalam prakteknya, beberapa produk yang memenuhi syarat untuk penurunan tarif di bawah skema FTA tidak benar-benar mendapatkan preferensi tarif seperti yang termuat dalam skema. Dalam pelaksanaan FTA yang sebenarnya, eksportir harus melakukan proses verifikasi untuk memperoleh tarif preferensi. Proses yang diperlukan untuk "memanfaatkan FTA" kadangkadang membutuhkan biaya yang signifikan bagi eksportir sehingga eksportir memutuskan untuk tidak menggunakan preferensi FTA, dan dengan demikian harus membayar tingkat tarif MFN (Itaravitak et al., 2011).

Literatur tentang pemanfaatan perjanjian perdagangan bebas barubaru ini berkembang pesat (Candau et.al, 2004; Takashi \& Urata, 2008; Takashi \& Urata, 2009; Keck \& Lendle,
2012; Athukorala \& Kohpaiboon, 2011; Itaravitak et.al, 2011; Kawai \& Wignaraja, 2011; Hayakawa et.al, 2013a; Kawai \& Wignaraja, 2013; Hayakawa et.al, 2014; Ing et.al, 2016) karena menjadi lebih penting untuk mendorong penggunaan FTA ditengah meroketnya jumlah-jumlah FTA yang terbentuk di seluruh dunia (Hayakawa, et al., 2013a). Menurut Okabe (2015) pemanfaatan FTA di ASEAN belum optimal untuk mempromosikan perdagangan antar negara ASEAN. Okabe (2015) menemukan masih terdapat permasalahan selain tarif seperti hambatan non tarif, fasilitas perdagangan antar anggota dan koordinasi Surat Keterangan Asal (SKA).

Dalam rangka meningkatkan akses pasar barang, Indonesia melakukan diplomasi perdagangan melalui multitrack strategy di fora multilateral, regional, dan bilateral. Melalui multitrack strategy ini, Indonesia telah memperkuat perannya di berbagai fora internasional, baik multilateral, yang bertumpu pada sistem perdagangan multilateral (WTO); regional, yang terfokus pada Association of Southeast 
Asian Nations (ASEAN) dan AsiaPacific Economic Cooperation (APEC); dan bilateral, yang berorientasi pada penjajakan pengembangan Comprehensive Economic Partnership dan FTA. Saat ini Indonesia telah memiliki dua kerja sama perdagangan bilateral yaitu Indonesia-Japan Economic Partnership Agreement (IJEPA) dan Indonesia-Pakistan Preferential Trade Agreement (IPPTA).

Sejak implementasi IJEPA tahun 2008, Indonesia seperti berhenti melakukan FTA bilateral dengan negara mitra dagang lainnya dan lebih memilih untuk melakukan FTA di bawah skema regional ASEAN. Kerja sama bilateral yang dilakukan Indonesia setelah IJEPA yaitu IPPTA yang memiliki cakupan liberalisasi lebih sedikit. Dengan demikian, sebagai contoh kerja sama perdagangan bilateral Indonesia yang sudah ada, kedua forum FTA ini memiliki karakteristik yang sangat berbeda. Pertanyaannya adalah apakah FTA yang komprehensif seperti IJEPA akan berpeluang untuk lebih dimanfaatkan oleh para pelaku usaha atau kerja sama Preferensial Trade Agreement yang fokus pada produkproduk yang menjadi minat ekspor utama Indonesia yang justru dapat dimanfaatkan secara optimal. Kajian ini mencoba menjawab pertanyaan tersebut dengan mengevaluasi tingkat pemanfaatan kedua forum FTA ini oleh pelaku usaha baik di sisi ekspor maupun di sisi impor.

\section{METODE}

Ada beberapa pendekatan untuk menghitung tingkat pemanfaatan FTA. Beberapa metode telah diusulkan dalam berbagai penelitian Candau et al., (2004) dan Inama (2003) menggunakan rasio cakupan FTA yang didefinisikan sebagai rasio pangsa nilai perdagangan untuk produk yang memenuhi skema FTA (eligible product) terhadap total perdagangan. Hayakawa et al., (2013a) mengukur pemanfaatan FTA melalui pangsa jumlah perusahaan pengguna. Lebih jauh Hayakawa (2014) menghitung akumulasi diagonal utilisasi FTA dan pengaruhnya terhadap trade creation effect pada FTA yang dilakukan oleh Jepang dan Thailand dalam kerangka bilateral dan multilateral.

Pada prinsipnya, ada dua pendekatan utama untuk menganalisis penggunaan FTA. Yang pertama dengan menggunakan catatan SKA dan yang kedua menggunakan metode survei terhadap perusahaan eksportir dan importir (Ing, et al, 2016). Masing- 
masing memiliki aspek positif dan negatif. Pendekatan yang didasarkan pada SKA memiliki dua aspek positif. Pertama, metode ini menyediakan informasi tentang penggunaan rinci FTA dengan produk. Kedua, tidak ada masalah sampel bias. Namun tantangan utamanya adalah ketersediaan data. Selain itu, data penggunaan SKA tidak memberikan informasi tentang karakteristik perusahaan. Penelitian yang menggunakan pendekatan ini adalah Ratananarumitsorn et.al (2008) dan Athukorala \& Kohpaiboon (2011).

Metode kedua untuk mengukur pemanfaatan FTA adalah dengan pendekatan survei seperti yang dilakukan oleh Takashi \& Urata (2008), Wignaraja et.al (2009), Zhang (2010), Itaravitak (2011), Keck \& Lendle (2012) dan Cheong (2014). Dua aspek positif utama dari pendekatan ini adalah, pertama, bahwa pendekatan ini menyediakan karakteristik perusahaan, yang memungkinkan kita untuk menganalisis bagaimana karakteristik perusahaan akan memengaruhi keputusan perusahaan untuk menggunakan FTA. Kedua, memungkinkan kita untuk mengamati motivasi untuk penggunaan FTA serta kendala pada penggunaannya.
Tantangan utama dari pendekatan survei adalah dari segi biaya dan waktu penelitian. Selain itu, ada masalah bias sampel dimana kualitas penelitian sangat bergantung pada strategi survei.

Untuk menghitung tingkat pemanfaatan IJEPA dan IPPTA penelitian ini akan menggunakan pendekatan yang didasarkan pada data penerbitan SKA sebagai ukuran pemanfaatan di sisi ekspor dengan mengikuti metode yang diusulkan oleh Ratananarumitsorn et.al (2008). Sementara untuk menghitung pemanfaatan di sisi impor menggunakan pendekatan eligible product dalam Inama (2003) dan Hayakawa et.al (2013a).

Untuk menghitung pemanfaatan FTA dari sisi ekspor digunakan data pemanfaatan SKA. Ratananarumitsorn et al., (2008), pemanfaatan FTA dengan menggunakan SKA didefinisikan sebagai rasio nilai ekspor yang dinyatakan dalam sertifikat SKA oleh eksportir untuk produk yang memperoleh preferensi tarif terhadap total ekspor semua produk yang layak memperoleh preferensi tarif. Pembilang, atau dalam hal ini adalah "nilai ekspor yang dinyatakan dalam sertifikat SKA" dapat diperoleh dari agregat nilai yang 
tertera pada setiap SKA yang diajukan. Sementara itu, penyebut, atau "nilai ekspor produk yang layak memperoleh preferensi tarif" diperoleh dari data BPS. Dengan demikian, pemanfaatan FTA dari sisi ekspor dinyatakan dengan:

Utilisasi $\quad$ Ekspor $=\frac{\text { Nilai Ekspor yang Dinyatakan dalam SKA }}{\text { Total Ekspor Indonesia ke Negara Mitra }}$

Kekurangan dari pendekatan ini adalah bahwa SKA di sisi eksportir kemungkinan akan gagal menerima tarif preferensi impor di negara mitra FTA. Dengan demikian angka tingkat pemanfaatan di sisi ekspor dengan pendekatan ini akan overestimate dari pemanfaatan yang terjadi di lapangan (Ratananarumitsorn et.al, 2008). Hayakawa et, al (2013b) menjelaskan bahwa selisih antara nilai yang tertera dalam SKA dengan realisasi ekspor berbanding positif terhadap tingkat volatilitas produk ekspor dan banyaknya pos tarif yang terdapat dalam kode Harmonized System (HS) 6 dijit yang sama.

Selain menghitung pemanfaatan FTA dalam nilai ekspor, penelitian ini juga menganalisis perkembangan jumlah perusahaan yang memanfaat- kan preferensi FTA untuk ekspor mereka. Analisis ini memanfaatkan pendekatan statistik dari penerbitan SKA per perusahaan. Selanjutnya untuk menghitung pemanfaatan dari sisi impor, penelitian ini mengikuti apa yang disarankan oleh Inama (2003) dan Hayakawa et.al (2013a) di mana pemanfataan FTA dihitung dengan rasio total nilai produk impor yang eligible terhadap total nilai impor. Definisi dari eligible product adalah produk yang memperoleh preferensi dan tingkat tarif preferensi lebih rendah dari tarif MFN. Untuk beberapa kasus, karena adanya penurunan tarif MFN secara unilateral memungkinkan tarif MFN menjadi lebih rendah dari tarif preferensi. Berdasarkan definisi tersebut, pemanfaatan FTA dari sisi impor dinyatakan dengan:

$$
\text { Utilisasi Impor }=\frac{\text { Total Impor Produk Eligible }}{\text { Total Impor Indonesia dari Negara Mitra }}
$$


Penelitian ini menggunakan data sekunder yaitu data realisasi penerbitan SKA IPPTA dan IJEPA per produk dan per perusahaan untuk tahun 2012-2016 yang bersumber dari Direktorat Fasilitasi, Kementerian Perdagangan. Data perdagangan ekspor dan impor diperoleh dari Badan Pusat Statistik (BPS).

\section{HASIL ANALISIS DAN PEMBAHASAN Perkembangan Indonesia-Jepang}

IJEPA mulai berlaku pada 1 juli 2008 melalui joint statement Menteri Luar Negeri Jepang dan Menteri Perdagangan Indonesia yang dilakukan di Tokyo, Jepang. Tujuan dari pembentukan IJEPA diantaranya untuk mendorong kelancaran perdagangan barang dan jasa serta meningkatkan arus investasi dan natural person antara kedua negara. IJEPA juga meliputi kerja sama peningkatan kapasitas dalam area kerja sama yang saling menguntungkan seperti industri pengolahan, pertanian, kehutanan dan kelautan (Ministry of Foreign Affairs of Japan, 2018).

Berdasarkan komitmen yang tertuang dalam kesepakatan IJEPA, Indonesia akan menurunkan tarif untuk 11.171 pos tarif atau $93 \%$ dari total pos tarif Indonesia (berdasarkan klasifikasi dalam Buku Tarif dan Bea Masuk Indonesia / BTBMI 2004) yang mewakili 93\% nilai impor Indonesia dari Jepang pada tahun 2006. Sementara Jepang memberikan penurunan tarif untuk 9.275 pos tarif atau sekitar 90\% dari total pos tarif Jepang yang mencakup 99\% ekspor Indonesia ke Jepang.

Berdasarkan data Badan Pusat Statistik, pada awal implementasi IJEPA, nilai ekspor Indonesia ke Jepang mengalami peningkatan dari USD 27,7 miliar pada tahun 2008 menjadi USD 33,7 miliar pada tahun 2011. Namun pada tahun-tahun selanjutnya ekspor Indonesia terus turun hingga menjadi USD 17,8 miliar pada tahun 2017. Impor Indonesia dari Jepang juga mengalami pola yang sama di mana peningkatan terjadi pada tahap awal implementasi dari USD 15,12 miliar pada tahun 2008 dan meningkat paling tinggi pada tahun 2012 yaitu sebesar USD 22,77 miliar kemudian secara bertahap turun menjadi USD 15,24 miliar pada tahun 2017. Selama periode tersebut neraca perdagangan Indonesia masih surplus terhadap Jepang walaupun terus menurun tiap tahunnya, terutama ekspor migas ke Jepang yang penurunannya sangat drastis. 


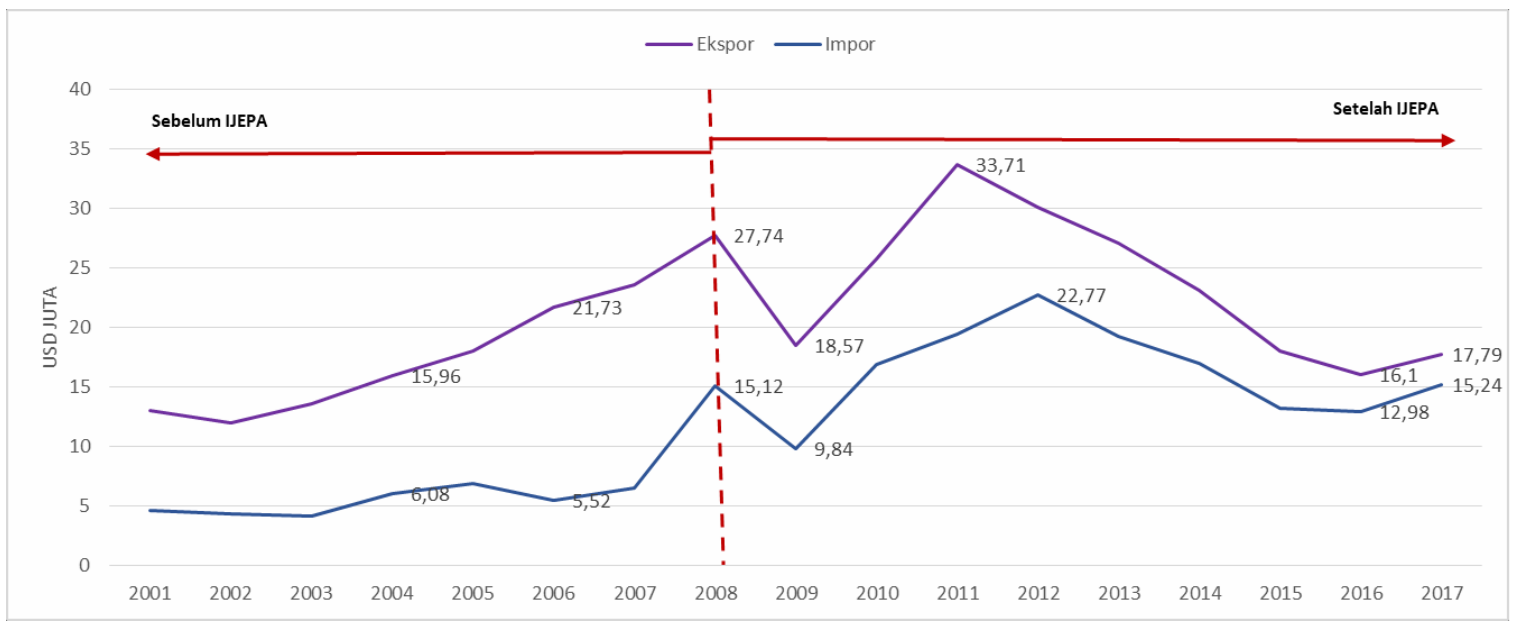

Gambar 1. Neraca Perdagangan Indonesia - Jepang, 2001-2017 (USD Juta)

Sumber: Trademap, (2018) diolah

Jika dicermati lebih lanjut kinerja pada umumnya merupakan barang perdagangan Jepang dengan Indonesia elektronik, mesin dan sukucadangnya. mencerminkan kinerja perdagangan Ekspor Jepang ke ASEAN juga Jepang secara umum. Gambar 2 didominasi oleh produk elektronik, menunjukkan bahwa ekspor Jepang ke mesin dan perlengkapannya selain juga negara ASEAN menurun pada tahun 2009 dan meningkat dengan puncak tertinggi pada tahun 2012 kemudian turun kembali hingga tahun 2017. Naikturunnya ekspor Jepang juga dipengaruhi oleh kondisi perdagangan dunia pada saat yang sama (Ando \& Kimura, 2012).

Dibandingkan dengan negara ASEAN lainnya, nilai impor Jepang dari Indonesia lebih tinggi sejak tahun 2006 hingga tahun 2013. Malaysia mulai mengambil pangsa impor Jepang sejak 2013 dan Thailand sejak 2015. Impor Jepang dari negara-negara ASEAN produk sukucadang kendaraan. Struktur perdagangan Jepang dengan negaranegara ASEAN tersebut mencerminkan bahwa negara ASEAN dipilih oleh perusahaan-perusahaan Jepang untuk membentuk jaringan produksi internasional di kawasan Asia Timur (Kawai, 2011). Tahakashi dan Urata (2008 dan 2009) juga menjelaskan bahwa perusahaan-perusahaan Jepang yang terkait dengan Foreign Direct Investment (FDI) di negara mitra FTA lebih banyak memanfaatkan tarif preferensi FTA dibanding perusahaan lainnya. 

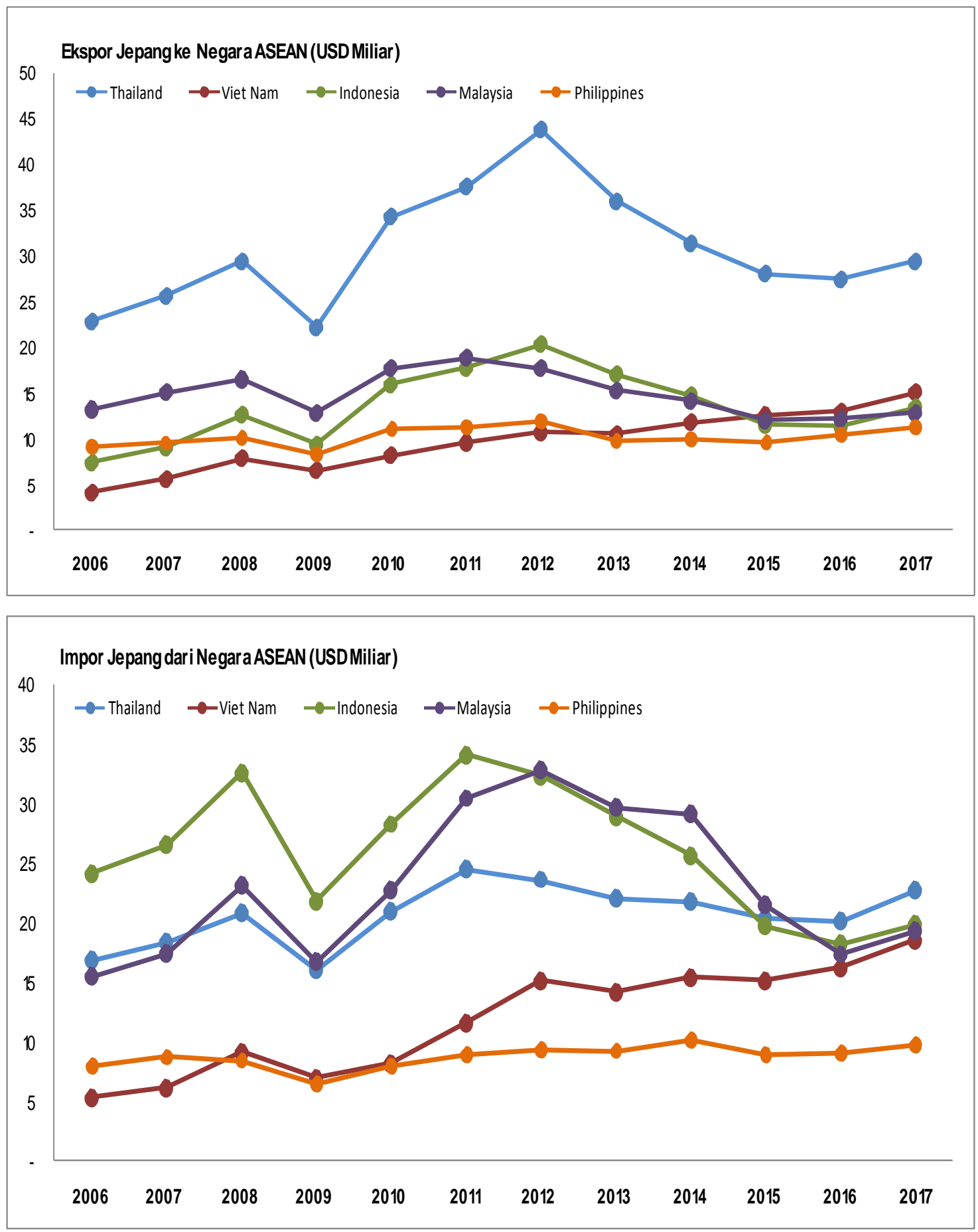

\section{Gambar 2. Ekspor dan Impor Jepang ke Negara-Negara ASEAN}

Sumber: Trademap (2018), diolah.

Kerja sama IJEPA yang sangat implementasinya. Ardiyanti (2015), liberal dan komprehensif dari cakupan Budiarti \& Hastiadi (2015) dan Gocklas dan kedalaman integrasi telah menarik \& Sulasmiyati (2017) menyimpulkan minat peneliti untuk mengevaluasi bahwa IJEPA memberi keuntungan bagi 
ekspor Indonesia. Ardiyanti (2015) memanfaatkan data ekspor dan impor bulanan dari tahun 1990 hingga 2014 dan menemukan bahwa IJEPA secara signifikan mampu meningkatkan kinerja ekspor non migas Indonesia ke Jepang namun tidak untuk impor non migas Indonesia dari Jepang. Budiarti \& Hastiadi (2015) menyimpulkan bahwa industri pengolahan Indonesia memanfaatkan tarif preferensi IJEPA untuk impor barang modal dan bahan baku yang kemudian menurunkan biaya produksi berupa Price Cost Margin (PCM). Skema IJEPA telah memperluas pangsa pasar ekspor industri pengolahan Indonesia.

Gocklas \& Sulasmiyati (2017) juga menyimpulkan setelah implementasi IJEPA nilai perdagangan kedua negara mengalami peningkatan signifikan dibanding sebelum implementasi. Setiawan (2012) menganalisis dampak tidak langsung IJEPA terhadap pendapatan nasional dan pertumbuhan ekspor. Setiawan (2012) menyimpulkan bahwa Indonesia menerima manfaat yang lebih besar dari Jepang dalam hal naiknya kontribusi ekspor terhadap pendapatan nasional secara nominal dan persentase. Setiawan (2012) juga menyimpulkan tingkat pertumbuhan ekspor Indonesia lebih tinggi dari pertumbuhan ekspor Jepang.

\section{Perkembangan \\ Perdagangan \\ Indonesia - Pakistan}

Berbeda dengan IJEPA, kerja sama Indonesia - Pakistan lebih sederhana dan hanya mencakup beberapa pos tarif yang diperdagangkan dalam bentuk IPPTA. Dalam IPPTA, disepakati bahwa Indonesia memperoleh preferensi akses pasar ke Pakistan sebanyak 313 pos tarif, sedangkan Pakistan mendapat preferensi akses pasar ke Indonesia sebanyak 232 pos tarif.

Implementasi IPPTA pada tahun 2013 mengakibatkan kenaikan ekspor Indonesia ke Pakistan sebesar $40 \%$ dari USD 1,4 miliar pada tahun 2013 menjadi USD 2 miliar pada tahun 2014. Ekspor Indonesia ke Pakistan didominasi oleh Palm Oil (HS 1511) dengan nilai ekspor pada tahun 2013 sebesar USD 800 ribu menjadi USD 1,3 juta pada satu tahun setelah implementasi. IPPTA ini telah menggesar dominasi Malaysia sebagai negara pemasok palm oil ke Pakistan.

Dalam kurun waktu lima tahun terakhir total perdagangan antara Indonesia dengan Pakistan pada mengalami kenaikan rata-rata $8.97 \%$ pertahun. Ekspor Indonesia ke Pakistan 
didominasi oleh produk non migas lainnya adalah kertas, benang, kulit dan seperti palm oil, kelapa, briket, pakaian. Nilai ekspor Indonesia ke kendaraan dan aksesoris kendaraan, Pakistan tumbuh rata-rata $12 \%$ serat dan benang, kertas dan produk pertahun, sedangkan nilai impor lainnya. Sementara itu, ekspor Pakistan meningkat rata-rata $10 \%$ pertahun. ke Indonesia sebagian besar Neraca perdagangan Indonesia merupakan produk pertanian seperti terhadap Pakistan selama periode beras, jeruk, kapas, tembakau dan ikan. 2012-2017 surplus dengan Produk ekspor Pakistan ke Indonesia pertumbuhan 15\% per tahun.

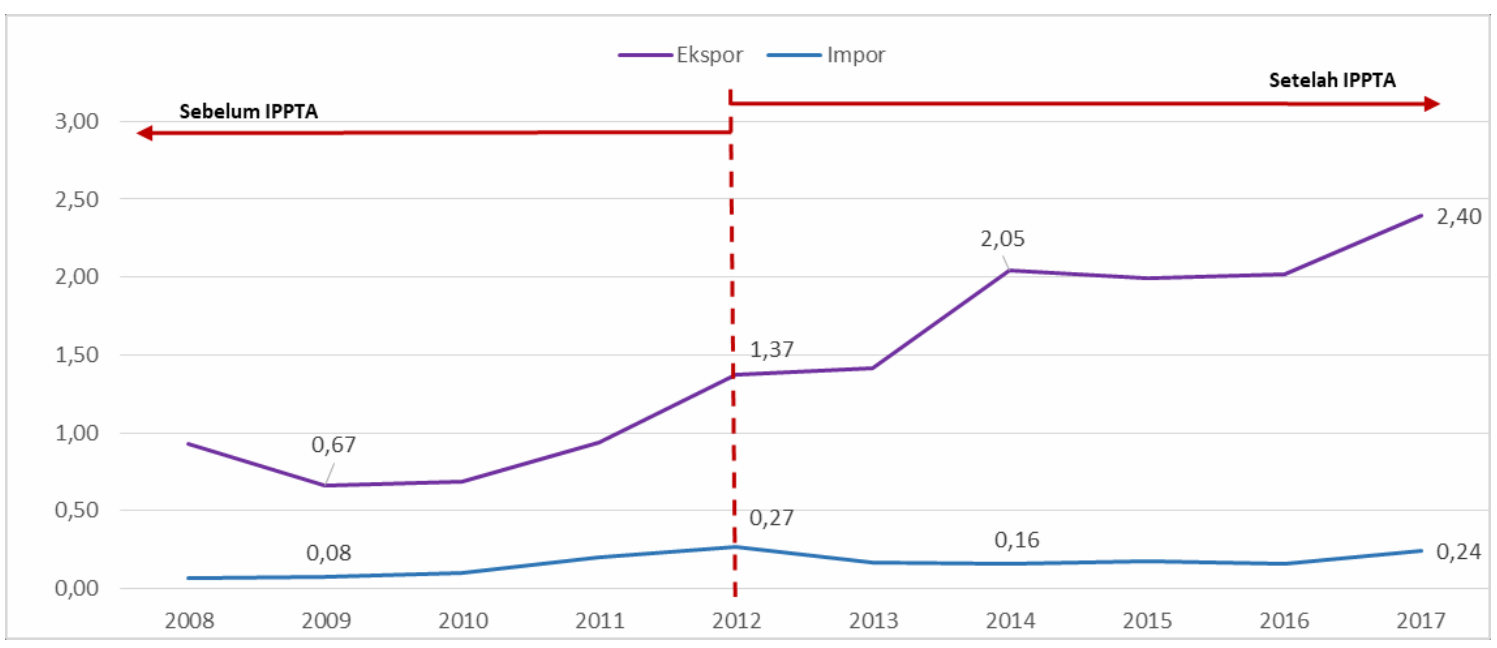

Gambar 3. Neraca Perdagangan Indonesia - Pakistan, 2008-2017 (USD Juta)

Sumber: Trademap (2018), diolah

Pemanfaatan Tarif Preferensi IJEPA dan IPPTA untuk Ekspor Indonesia

Literatur yang mengukur tingkat pemanfaatan FTA di Indonesia masih terbatas terutama yang menghitung pemanfaatan kerja sama IPPTA. Sitepu \& Nurhidayat (2015) telah membandingkan pemanfaatan FTA Indonesia untuk ASEAN FTA (AFTA), ASEAN-China FTA (ACFTA); ASEANKorea FTA (AKFTA), ASEAN-India FTA
(AIFTA) dan IJEPA namun tidak menyertakan penelitiannya untuk IPPTA. Sitepu \& Nurhidayat (2015) menemukan bahwa tingkat coverage rate dalam FTA Indonesia yang tinggi tidak diikuti oleh tingkat pemanfaatanya. Rata-rata coverage rate pada FTA yang dianalisis oleh Sitepu \& Nurhidayat (2015) adalah di atas 90\% namun ratarata tingkat pemanfaatan FTAnya hanya $28 \%$. Tingkat pemanfaatan paling tinggi 
adalah pada ACFTA yaitu $35,98 \%$ diikuti oleh AKFTA 33,61\%, IJEPA 32,65\%, AFTA $30,43 \%$ dan yang paling rendah adalah AIFTA 6,05\%.

Penelitian menunjukkan bahwa penurunan tarif tidak serta menjadi insentif bagi pengusaha untuk memanfaatkan tarif preferensi tersebut. Cheong (2014), Ing et.al (2016), Hayakawa et.al (2016), Takashi \& Urata (2008 dan 2009), Zhang (2011) menemukan bahwa tingkat pemanfaatan FTA sangat ditentukan oleh karakteristik perusahaan. Hal ini terkait dengan biaya yang dikeluarkan dan tingkat kerumitan dalam proses penerbitan Surat Keterangan Asal atau SKA (Wignaraja et.al, 2009; Itaravitak, 2011; Keck \& Lendle, 2012; dan Hayakawa \& Laksanapanyakul, 2017). Tingkat pemanfaatan FTA juga bervariasi untuk produk ekspor (Cheong, 2014; Hayakawa et.al, 2016). Tingkat pemanfaatan ekspor Indonesia dalam kerangka IJEPA dalam periode 2012-2016 cenderung stagnan. Pada tahun 2012 pemanfaatan IJEPA untuk ekspor ke Jepang sebesar 47,7\%. Pada tahun 2013 tingkat pemanfaatannya naik menjadi 59,7\% namun setelah itu secara bertahap kembali pada tingkat $47,2 \%$ pada tahun 2016 . Secara rata- rata tingkat pemanfaatan ekspor dalam IJEPA turun sebesar 1,2\% per tahun. Rendahnya utilisasi FTA tidak hanya terjadi pada kasus IJEPA. Pada FTA yang lain seperti AFTA, ACFTA, dan AKFTA, tingkat pemanfaatan juga rendah. Menurut Sitepu \& Nurhidayat (2015) beberapa penyebab yang mungkin menjadi penyebab rendahnya pemanfaatan FTA tersebut karena perbedaan yang tidak terlalu signifikan antara tarif MFN dan tarif preferensi; Prosedur yang harus dijalani untuk dapat menggunakan tarif preferensial dianggap cukup menyulitkan (compliance cost tinggi). Kesalahan identifikasi dalam sistem komputer pabean yang merekam data Pemberitahuan Impor Barang (PIB) dalam hal importasi menggunakan beberapa skema fasilitas.

Berbeda dengan IJEPA, tingkat pemanfaatan IPPTA selama 2013-2016 untuk ekspor Indonesia ke Pakistan mengalami pertumbuhan yang signifikan yaitu $31,6 \%$ per tahun. Pada tahun 2013 yaitu awal implementasi IPPTA, tingkat pemanfaatan untuk ekspor sebesar $29,3 \%$. Angka tersebut terus meningkat pesat pada tahun 2013 menjadi $71,7 \%$. Selanjutnya tingkat pemanfaatan IPPTA terus berada pada 
level di atas $70 \%$. Pemanfaatan IPPTA untuk ekspor ke Pakistan yang tinggi terutama digunakan untuk ekspor produk Crude Palm Oil (CPO). Produk CPO mengalami peningkatan ekspor yang signifikan sejak IPPTA berlaku.

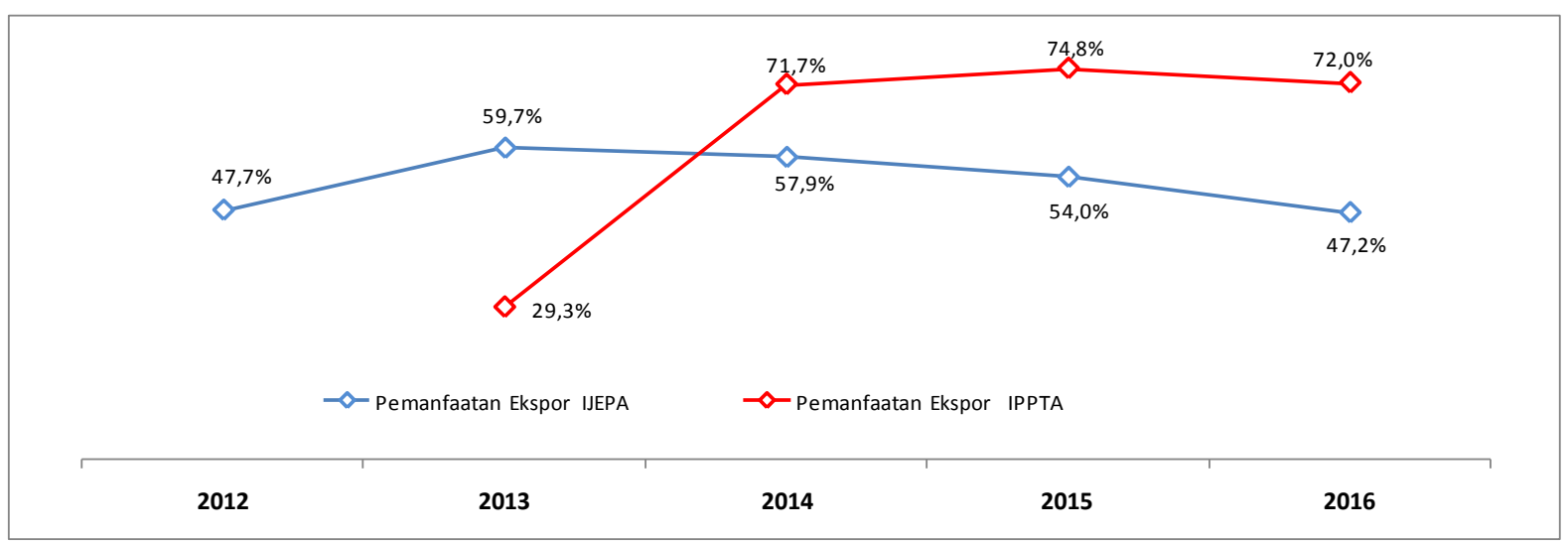

\section{Gambar 4. Tingkat Pemanfaatan Tarif Preferensi untuk Ekspor Indonesia dalam Kerangka IJEPA dan IPPTA}

Sumber: Hasil Perhitungan Penulis

Tingginya tingkat pemanfaatan IPPTA di sisi ekspor Indonesia didorong oleh ekspor minyak sawit yang berhasil memanfaatkan tarif preferensi ke Pakistan. IPPTA telah meningkatkan neraca perdagangan Indonesia dengan Pakistan dari surplus USD 1,2 miliar pada tahun 2013 menjadi surplus 2,2 miliar pada tahun 2017. Kebutuhan Pakistan akan minyak sawit Indonesia mendongkrak secara signifikan ekspor produk tersebut. Selain minyak sawit, beberapa produk ekspor utama Indonesia ke Pakistan mengalami kenaikan ekspor, antara lain buah pinang, batubara, kendaraan penumpang, suku cadang kendaraan, dan serat stapel.

Pemanfaatan Preferensi IJEPA dan IPPTA untuk Ekspor Berdasarkan Produk

Menurut Cheong (2014) tingkat pemanfaatan FTA bervariasi antar sektor perdagangan. Hal ini didukung Hayakawa et.al (2016) yang menemukan bahwa biaya yang ditimbulkan untuk penerbitan SKA berbeda antar sektor industri sehingga skala perusahaan pada akhirnya menentukan apakah pengusaha akan memanfaatkan tarif preferensi atau tidak. Menurut Takashi \& Urata (2008 dan 2009) tingkat 
pemanfaatan tarif preferensi oleh perusahaan Jepang masih rendah dan perusahaan besar cenderung memiliki tingkat pemanfaatan yang lebih tinggi dibandingkan perusahaan yang lebih kecil. Rendahnya pemanfaatan tarif preferensi terjadi pada perusahaan Jepang yang berafiliasi di negara mitra karena perusahaan tersebut menggunakan insentif dari skema investasi.
Tabel 1 menggambarkan tingkat pemanfaatan IJEPA 20 sektor yang memiliki nilai penerbitan SKA paling tinggi. 20 sektor tersebut mewakili 56\% dari total nilai ekspor yang tercantum dalam SKA. Rata-rata tarif yang berlaku dalam kerangka IJEPA sudah cukup rendah dan sudah 0\%. Hanya footwear dan produk coffee, tea, mate and spices yang memiliki tarif masing-masing $2,78 \%$ dan $0,77 \%$.

\section{Tabel 1. Pemanfaatan Tarif Preferensi IJEPA Untuk Ekspor Berdasarkan Produk}

\begin{tabular}{|c|c|c|c|c|c|c|}
\hline $\begin{array}{l}\text { HS } 2 \\
\text { dijit }\end{array}$ & Deskripsi & $\begin{array}{l}\text { Nilai SKA } \\
2016 \\
\text { (USD Juta) }\end{array}$ & $\begin{array}{l}\text { Rata-rata Tarif } \\
\text { IJEPA per2016 }\end{array}$ & $\begin{array}{l}\text { Pemanfaatan } \\
\text { FTA } 2012\end{array}$ & $\begin{array}{l}\text { Pemanfaatan } \\
\text { FTA } 2016\end{array}$ & Keterangan \\
\hline 26 & Ores, slag and ash & 464,78 & - & 60 & 36 & $\downarrow$ \\
\hline 44 & Wood and articles of wood & 375,62 & - & 46 & 50 & $\uparrow$ \\
\hline 39 & Plastics & 372,45 & 0,00 & 88 & 91 & $\uparrow$ \\
\hline 3 & Fisheries & 302,73 & - & 60 & 73 & $\uparrow$ \\
\hline 64 & Footwear & 217,77 & 2,76 & 71 & 71 & $\leftrightarrow$ \\
\hline 62 & Apparel not knited & 209,89 & - & 70 & 61 & $\downarrow$ \\
\hline 61 & Apparel knited & 186,79 & - & 76 & 61 & $\downarrow$ \\
\hline 29 & Organic chemicals & 180,97 & 0,02 & 85 & 85 & $\leftrightarrow$ \\
\hline 15 & Animal,vegetable fats and oil & 176,61 & - & 91 & 95 & $\uparrow$ \\
\hline 55 & Manmade staple fibres & 157,40 & - & 96 & 94 & $\downarrow$ \\
\hline 52 & Cotton & 107,76 & - & 90 & 94 & $\uparrow$ \\
\hline 94 & Furniture & 80,29 & - & 33 & 43 & $\uparrow$ \\
\hline 28 & Inorganic chemicals & 76,27 & - & 89 & 93 & $\uparrow$ \\
\hline 54 & Manmade filaments & 69,15 & - & 91 & 79 & $\downarrow$ \\
\hline 9 & $\begin{array}{l}\text { Coffee, tea, mate and spices } \\
\text { Miscellaneous chemical }\end{array}$ & 63,09 & 0,77 & 47 & 55 & $\uparrow$ \\
\hline 38 & products & 61,60 & - & 93 & 87 & $\downarrow$ \\
\hline 63 & $\begin{array}{l}\text { Other made textile articles } \\
\text { Meat, fish and seafood food }\end{array}$ & 58,28 & - & 93 & 88 & $\downarrow$ \\
\hline 16 & $\begin{array}{l}\text { preparations nes } \\
\text { Wadding, felt, nonwovens, }\end{array}$ & 58,23 & - & 48 & 48 & $\leftrightarrow$ \\
\hline 56 & yarns, twine, cordage & 37,97 & - & 93 & 95 & $\uparrow$ \\
\hline 14 & Vegetable plaiting materials & 35,51 & - & 99 & 100 & $\uparrow$ \\
\hline
\end{tabular}

Sumber : Hasil kalkulasi penulis 
Sektor yang paling tinggi nilai pengajuan ekspor dalam SKA adalah Ores and, Slag and ash; Wood and article of woods; dan plastics. Tabel 1 menunjukkan bahwa nilai pengajuan ekspor dalam SKA yang tinggi tidak harus diikuti oleh nilai pemanfaatan yang tinggi pula. Misalnya pada Ores, slag and ash pemanfaatannya hanya $36 \%$ walaupun nilai pengajuan SKAnya merupakan yang paling tinggi. Sementara vegetable plating materials memiliki tingkat pemanfaaan IJEPA sebesar $100 \%$.

Sebagian sektor perdagangan mengalami kenaikan tingkat pemanfaatan IJEPA seperti wood, plastic, fisheries, animal and vegetable fats and oil. Kenaikan tingkat pemanfaatan tarif preferensi adalah hal yang seharusnya, mengingat margin preferensi yang menurun tiap tahun (Keck \& Lendle, 2012). Namun demikian beberapa sektor perdagangan mengalami penurunan tingkat pemanfaatan IJEPA seperti Ores, slag and ash, apparel, manmade staple fibres, manmade filament, chemical product dan other made textile. Menurut Keck \& Lendle (2012) salah satu faktor perubahan tingkat pemanfaatan FTA adalah perubahan pada nilai perdagangannya. Namun hipotesis itu tidak terjadi pada produk ores slag and ash, apparel, dan man made textile.

Tabel 2 menunjukkan produk ekspor Indonesia ke Pakistan yang menggunakan SKA untuk melakukan ekspornya. Dapat dilihat bahwa Animal, vegetable fats and oil memiliki nilai pemanfaatan IPPTA yang tertinggi sebesar USD 1,1 miliar dollar. Tingkat pemanfaatannya pun meningkat tajam dari hanya 38\% pada tahun 2013 menjadi 89\% pada tahun 2016. Peningkatan penggunanaan IPPTA juga terjadi pada sebagian besar produk ekspor unggulan Indonesia ke Pakistan. Hanya beberapa produk saja yang tingkat pemanfaatan IPPTA nya mengalami penurunan, seperti Miscellaneous manufactured articles Tanning, dyeing extracts, dan Lac, gums, resins, vegetable saps and extracts nes.

Dalam kasus IPPTA cakupan produk Indonesia yang mendapat preferensi di Pakistan hanya 313 pos tarif namun produk tersebut merupakan ekspor unggulan Indonesia ke Pakistan. Pada tahun 2016 jumlah produk yang diajukan penerbitan SKA ke Pakistan sebanyak 193 produk. Pada Tabel 3, 20 produk dengan nilai pengajuan SKA 
tertinggi telah mewakili $99 \%$ total nilai SKA IPPTA. SKA minyak sawit sendiri sudah mencakup $90 \%$ nilai total SKA.
Tabel 2 mengkonfirmasi pemanfaatan IPPTA didominasi oleh produk minyak sawit Indonesia ke Pakistan.

\section{Tabel 2. Pemanfaatan Preferensi IP-PTA untuk Ekspor (Sektor), 2013-2016}

\begin{tabular}{|c|c|c|c|c|c|}
\hline $\begin{array}{l}\text { HS } 2 \\
\text { dijit }\end{array}$ & Deskripsi & $\begin{array}{l}\text { Nilai SKA } 2016 \\
\quad \text { (USD ) }\end{array}$ & $\begin{array}{l}\text { Pemanfaatan } \\
\text { FTA } 2013\end{array}$ & $\begin{array}{l}\text { Pemanfaatan } \\
\text { FTA } 2016\end{array}$ & Keterangan \\
\hline 15 & Animal,vegetable fats and oil & $1.161,1$ & 38 & 89 & $\uparrow$ \\
\hline 48 & Paper and paperboard & 30,5 & 6 & 70 & $\uparrow$ \\
\hline 8 & Edible fruit, nuts & 23,4 & 10 & 17 & $\uparrow$ \\
\hline 40 & Rubber and articles thereof & 20,5 & 34 & 75 & $\uparrow$ \\
\hline 18 & Cocoa and cocoa preparations & 12,4 & 14 & 95 & $\uparrow$ \\
\hline 9 & Coffee, tea, mate and spices & 8,6 & 30 & 48 & $\uparrow$ \\
\hline 38 & Miscellaneous chemical products & 8,1 & 35 & 62 & $\uparrow$ \\
\hline 27 & Mineral fuels, oil & 5,0 & 33 & 24 & $\uparrow$ \\
\hline 34 & Soaps, lubricants, waxes, candle & 3,2 & 5 & 16 & $\uparrow$ \\
\hline 29 & $\begin{array}{l}\text { Organic chemicals } \\
\text { Essential oils, perfumes }\end{array}$ & 2,3 & 20 & 29 & $\uparrow$ \\
\hline 33 & cosmetics, toileteries & 1,8 & 1 & 32 & $\uparrow$ \\
\hline 39 & Plastics and articles thereof & 1,6 & 52 & 72 & $\uparrow$ \\
\hline 55 & Manmade staple fibres & 1,5 & 1 & 7 & $\uparrow$ \\
\hline 23 & $\begin{array}{l}\text { Residues, wastes of food industry } \\
\text { Miscellaneous manufactured }\end{array}$ & 1,4 & 10 & 15 & $\uparrow$ \\
\hline 96 & articles & 0,7 & 16 & 12 & $\downarrow$ \\
\hline 32 & Tanning, dyeing extracts & 0,6 & 34 & 16 & $\downarrow$ \\
\hline 69 & Ceramic products & 0,4 & 11 & 46 & $\uparrow$ \\
\hline 21 & $\begin{array}{l}\text { Miscellaneous edible preparations } \\
\text { Lac, gums, resins, vegetable saps }\end{array}$ & 0,3 & 60 & 93 & $\uparrow$ \\
\hline 13 & and extracts nes & 0,3 & 32 & 30 & $\downarrow$ \\
\hline 52 & Cotton & 0,2 & - & 54 & $\uparrow$ \\
\hline
\end{tabular}

Sumber : Hasil Kalkulasi Penulis

\section{Pertumbuhan Perusahaan Pengguna} SKA

Secara

nasional jumlah perusahaan yang menerbitkan SKA preferensi FTA di Indonesia pada tahun 2012 sebanyak 6.325 perusahaan dan meningkat di tahun 2016 sebanyak 7.208 perusahaan. Pertumbuhan jumlah perusahaan yang menerbitkan
SKA dalam periode 2012-2016 adalah $3,3 \%$ per tahun. Jika dibandingkan tahun 2015, peningkatan jumlah perusahaan yang menggunakan SKA tahun 2016 meningkat 2,65\%. Menurunnya pertumbuhan jumlah perusahaan yang menggunakan SKA preferensi menjadi indikasi dari jumlah pertumbuhan perusahaan eksportir 
yang juga menurun atau pemanfaatan SKA oleh perusahaan sudah memasuki titik jenuhnya.

Perusahaan atau eksportir yang mengajukan penerbitan SKA untuk skema IJEPA sudah cukup banyak jika dibandingkan dengan skema IPPTA. Hal tersebut dikarenakan cakupan produk dalam komitmen IJEPA jauh lebih luas dari pada IPPTA. Selain itu, IJEPA sudah cukup lama diimplementasikan sehingga eksportir sudah cukup paham dengan keberadaan IJEPA Namun demikian pertumbuhan pengguna SKA IJEPA selama 20122016 relatif rendah yaitu 2,6\% per tahun. Hal tersebut menunjukkan bahwa jumlah pengguna skema IJEPA sudah pada level jenuh. Pertumbuhan jumlah perusahaan pengguna skema IPPTA masih tumbuh 18,2\% per tahun.

Sebaran perusahaan pengguna SKA IJEPA terkonsentrasi pada wilayah
Jakarta sebanyak 614 perusahaan, Jawa Timur (398), Jawa Barat (392), Jawa Tengah (227), Bali (100), Jogjakarta (80) dan Sumatera Utara (78). Dengan demikian, pemanfaatan IJEPA masih didominasi perusahaanperusahaan di pulau Jawa dengan hampir $80 \%$ dari total perusahaan yang mengajukan SKA IJEPA secara nasional. Sementara itu perusahaan yang mengajukan SKA IPPTA paling banyak di Jakarta sebanyak 78 perusahaan, Jawa Timur 61 perusahaan dan Sumatera Utara sebanyak 58 perusahaan. Jika dilihat dari nilai ekspor yang diajukan dalam SKA, daerah yang paling tinggi nilai ekspor menggunakan SKA IPPTA adalah Dumai (salah satu daerah di Sumatera) dengan jumlah perusahaan sebanyak 15 dan nilai ekspor USD 568 juta atau $39 \%$ dari total ekspor dengan SKA IPPTA.

\section{Tabel 3. Pertumbuhan Perusahaan Pengguna SKA Periode 2012-2016}

\begin{tabular}{ccc}
\hline \multirow{2}{*}{ Tahun } & \multicolumn{2}{c}{$\begin{array}{c}\text { Jumlah Perusahaan yang Menggunakan } \\
\text { SKA Ekspor }\end{array}$} \\
\cline { 2 - 3 } & IJEPA & IP PTA \\
\hline 2012 & 1.792 & 169 \\
2013 & 1.889 & 283 \\
2014 & 1.97 & 305 \\
2015 & 1.98 & 288 \\
2016 & 1.986 & $\mathbf{1 8 , 2 0 \%}$ \\
\hline
\end{tabular}

Sumber : Hasil Kalkulasi Penulis 
Pemanfaatan Tarif Preferensi IJEPA dan IPPTA dalam Impor Indonesia

Pemanfaatan IPPTA di sisi impor masih rendah rata-rata $15 \%$ per tahun (2012-2016). Namun, pertumbuhan pemanfaatannya tumbuh rata-rata $30 \%$ per tahun dalam periode yang sama. Pada tahun 2013 pemanfaatan impor yang menggunakan skema IPPTA hanya sebesar $8,3 \%$, terus meningkat hingga tahun 2016 menjadi 18,8\%.
Sementara itu pemanfaatan impor dengan skema IJEPA di sisi impor selama periode 2012-2016 meningkat sekitar 3\% dari angka 60,7\% pada tahun 2012 menjadi 67,7\% per tahun. Ratarata pemanfaatan IJEPA untuk impor selama 2012-2016 adalah 64,3\%. Dilihat dari nilai utilisasi impor yang cenderung naik, hal ini menunjukkan importir semakin memanfaatkan fasilitas perjanjian perdagangan.

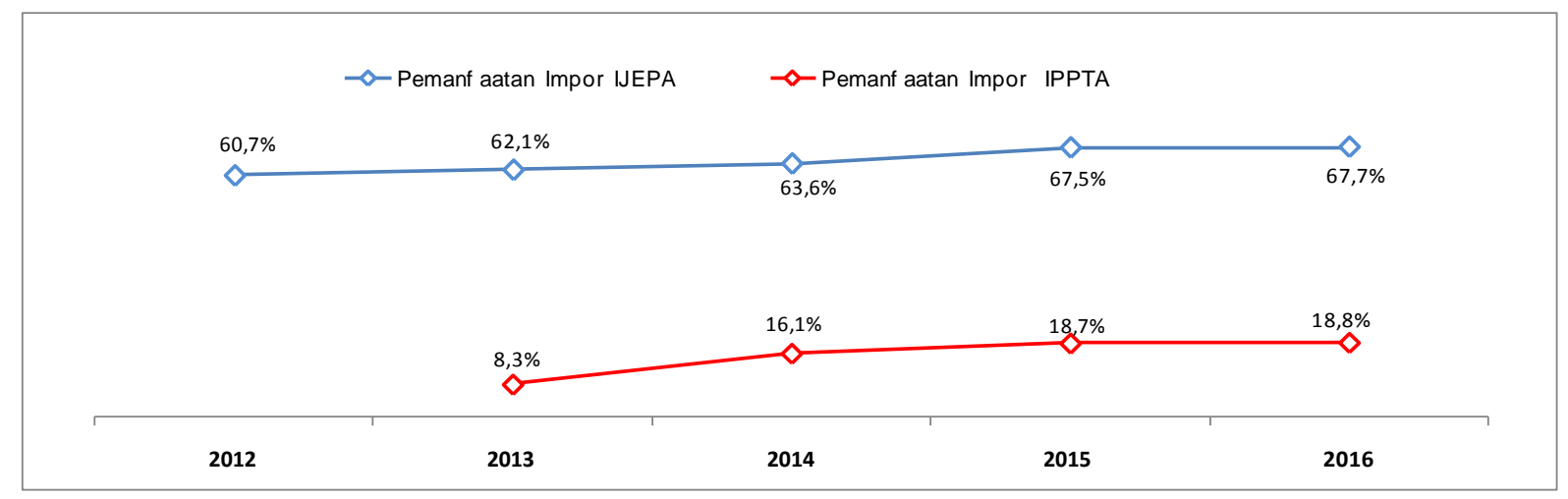

Gambar 5. Nilai Utilisasi Impor Indonesia dalam IP-PTA dan IJEPA, 2012-2016 (\%)

Sumber: Hasil kalkulasi penulis

Pemanfaatan Preferensi IJEPA dan IPPTA untuk Impor Berdasarkan Produk

Cakupan produk yang memperoleh preferensi IJEPA cukup luas yaitu mencapai $93 \%$ dari total pos tarif Indonesia. Tabel 4 memuat produk dalam HS 2 digit (chapter) yang memiliki nilai impor Indonesia dari Jepang yang paling tinggi. Rata-rata tarif Indonesia untuk Jepang dalam kerangka IJEPA sudah relatif rendah bahkan $0 \%$ seperti tanning, dyeing extract; manmade staple fibres; paper and paperboard; manmade filaments; soaps, lubricants, waxes, candles; miscellaneous article of base metal. Produk yang lainnya juga memiliki rata-rata tarif yang hampir nol. 
Tabel 4. Pemanfaatan Tarif Preferensi IJEPA dalam Impor Indonesia Berdasarkan Produk

\begin{tabular}{|c|c|c|c|c|c|c|}
\hline $\begin{array}{r}\text { HS } 2 \\
\text { dijit }\end{array}$ & Deskripsi & $\begin{array}{l}\text { Rata-rata } \\
\text { Tarif dalam } \\
\text { Kerangka } \\
\text { IJEPA }\end{array}$ & $\begin{array}{c}\text { Nilai Impor } \\
\text { Eligible Produk } \\
2016 \text { (USD Juta) }\end{array}$ & $\begin{array}{c}\text { Pemanfaatan } \\
\text { FTA } 2012\end{array}$ & $\begin{array}{c}\text { Pemanfaatan } \\
\text { FTA } 2016\end{array}$ & Keterangan \\
\hline 84 & Machinery & 0,1 & $2.558,0$ & 74,9 & 76,3 & $\uparrow$ \\
\hline 87 & $\begin{array}{l}\text { Vehicles other than railway } \\
\text { Electrical, electronic }\end{array}$ & 1,7 & $1.609,8$ & 98,7 & 99,8 & $\uparrow$ \\
\hline 85 & equipment & 0,2 & 882,1 & 50,6 & 57,7 & $\uparrow$ \\
\hline 39 & Plastics and articles thereof & 1,7 & 639,4 & 92,0 & 90,0 & $\downarrow$ \\
\hline 40 & Rubber and articles thereof & 0,2 & 438,2 & 100,0 & 100,0 & $\leftrightarrow$ \\
\hline 72 & $\begin{array}{l}\text { Iron and steel } \\
\text { Optical, photo, technical, }\end{array}$ & 9,5 & 414,2 & 22,7 & 28,7 & $\uparrow$ \\
\hline 90 & medical & 0,1 & 323,9 & 87,8 & 87,2 & $\downarrow$ \\
\hline 29 & Organic chemicals & 0,0 & 207,5 & 62,1 & 70,0 & $\uparrow$ \\
\hline 73 & $\begin{array}{l}\text { Articles of iron or steel } \\
\text { Miscellaneous chemical }\end{array}$ & 7,6 & 195,8 & 28,9 & 32,4 & $\uparrow$ \\
\hline 38 & products & 0,1 & 175,0 & 96,7 & 92,7 & $\leftrightarrow$ \\
\hline 32 & Tanning, dyeing extracts & - & 97,7 & 54,2 & 54,0 & $\downarrow$ \\
\hline 55 & Manmade staple fibres & - & 91,9 & 65,5 & 74,0 & $\uparrow$ \\
\hline 28 & Inorganic chemicals & 0,1 & 90,9 & 82,5 & 83,0 & $\uparrow$ \\
\hline 48 & $\begin{array}{l}\text { Paper and paperboard } \\
\text { Stone, plaster, cement, }\end{array}$ & - & 77,0 & 99,8 & 99,9 & $\uparrow$ \\
\hline 68 & asbestos, mica & 0,7 & 69,7 & 100,0 & 100,0 & $\leftrightarrow$ \\
\hline 81 & Other base metals & 0,7 & 63,3 & 92,8 & 97,0 & $\uparrow$ \\
\hline 54 & $\begin{array}{l}\text { Manmade filaments } \\
\text { Aluminium and articles }\end{array}$ & - & 56,4 & 100,0 & 100,0 & $\leftrightarrow$ \\
\hline 76 & $\begin{array}{l}\text { thereof } \\
\text { Soaps, lubricants, waxes, }\end{array}$ & 0,2 & 56,2 & 88,8 & 87,3 & $\downarrow$ \\
\hline 34 & $\begin{array}{l}\text { candles } \\
\text { Miscellaneous articles of }\end{array}$ & - & 56,1 & 74,3 & 74,5 & $\uparrow$ \\
\hline 83 & base metal & - & 53,3 & 100,0 & 100,0 & $\leftrightarrow$ \\
\hline
\end{tabular}

Sumber: Hasil kalkulasi penulis

Berdasarkan kelompok produk HS 2 digit pemanfaatan IJEPA untuk beberapa produk cukup tinggi yaitu di atas $90 \%$ seperti vehicle; plastic; rubber and article thereof; mescellaneous

chemical product; paper; other base metal; manmade filaments; dan miscellaneous article of base of metal. Hampir semua produk juga mengalami peningkatan pemanfaatan IJEPA. 
Tabel 5. Pemanfaatan Tarif Preferensi IPPTA dalam Impor Indonesia Berdasarkan Produk

\begin{tabular}{|c|c|c|c|c|c|c|}
\hline $\begin{array}{l}\text { HS } 2 \text { dijit } \\
\text { (Chapter) }\end{array}$ & Deskripsi & $\begin{array}{l}\text { Rata-rata Tarif } \\
\text { Indonesia } \\
\text { untuk Pakistan }\end{array}$ & $\begin{array}{l}\text { Nilai Impor } \\
\text { Eligible } \\
\text { Produk } \\
\text { (USD Ribu) }\end{array}$ & $\begin{array}{l}\text { Pemanfaatan } \\
\text { IPPTA } 2013\end{array}$ & $\begin{array}{l}\text { Pemanfaatan } \\
\text { IPPTA } 2016\end{array}$ & Keterangan \\
\hline 40 & Rubber and articles thereof & 5,0 & $5.238,1$ & 16,6 & 17,2 & $\uparrow$ \\
\hline 73 & Articles of iron or steel & 3,6 & $4.618,1$ & 80,5 & 60,4 & $\downarrow$ \\
\hline 32 & Tanning, dyeing extracts & - & $3.504,4$ & 65,6 & 70,2 & $\uparrow$ \\
\hline 24 & Tobacco and manufactured & 9,5 & $2.231,4$ & 14,6 & 100,0 & $\uparrow$ \\
\hline 54 & Manmade filaments & 4,8 & $1.093,5$ & 53,3 & 32,8 & $\downarrow$ \\
\hline 33 & $\begin{array}{l}\text { Essential oils } \\
\text { Cereal, flour, starch, milk }\end{array}$ & 5,0 & 969,3 & 7,1 & 10,8 & $\uparrow$ \\
\hline 19 & preparation & 3,1 & 776,5 & 43,3 & 31,5 & $\downarrow$ \\
\hline 55 & $\begin{array}{l}\text { Manmade staple fibres } \\
\text { Machinery, nuclear reactors, }\end{array}$ & 3,8 & 592,4 & 0,2 & 0,6 & $\uparrow$ \\
\hline 84 & $\begin{array}{l}\text { boilers, etc } \\
\text { Special woven or tufted }\end{array}$ & 1,3 & 462,6 & 2,1 & 4,9 & $\uparrow$ \\
\hline 58 & fabric & 2,5 & 449,9 & 99,9 & 99,6 & $\downarrow$ \\
\hline 52 & $\begin{array}{l}\text { Cotton } \\
\text { Miscellaneous manufactured }\end{array}$ & 1,5 & 446,3 & 1,3 & 19,6 & $\uparrow$ \\
\hline 96 & articles & 9,0 & 113,3 & 0,1 & 0,8 & $\uparrow$ \\
\hline 08 & Edible fruit, nuts & - & 1,9 & 0,03 & 0,00 & $\downarrow$ \\
\hline 82 & Tools, implements, cutlery & 4,3 & 0,5 & - & 0,1 & $\uparrow$ \\
\hline 61 & Articles of apparel knit & 7,0 & 0,4 & 6,0 & 0,1 & $\downarrow$ \\
\hline 50 & Silk & 2,5 & 0,3 & - & 100,0 & $\uparrow$ \\
\hline 42 & Articles of leather & 4,4 & 0,1 & - & 86,3 & $\uparrow$ \\
\hline
\end{tabular}

Sumber : Hasil kalkulasi penulis

Jumlah produk impor Indonesia asal Pakistan yang diberikan tarif preferensi dalam kerangka IPPTA sebanyak 232 pos tarif. Produk tersebut tersebar dalam 31 chapter (HS 2 digit) namun yang memiliki nilai impor Indonesia dari Pakistan hanya sebanyak 17 chapter. Selama periode 2013-2016 impor Indonesia dari Pakistan tidak mengalami lonjakan yang berarti seperti yang terjadi pada sisi ekspor Indonesia ke Pakistan. Bahkan nilainya cenderung turun sebesar $1 \%$.
Produk yang mengalami peningkatan impor diantaranya adalah tanning; manmad filaments; manmade staple fibres; edible fruits; tools, implements, cutlery; dan article of apparel knitted. Produk yang lainnya justru mengalami penurunan nilai impor dari Pakistan. Mencermati kinerja impor Indonesia dari Pakistan untuk produk eligible yang memperoleh preferensi terlihat bahwa dampak IPPTA lebih banyak mendorong ekspor Indonesia dibandingkan ekspor Pakistan. 
Tingkat pemanfaatan IPPTA berdasarkan produk secara umum juga relatif rendah. Produk rubber and article thereof yang memiliki nilai impor paling tinggi hanya memiliki tingkat pemanfaatan IPPTA $17,2 \%$. Tingkat pemanfaatan edible fruits dalam skala agregat HS 2 digit bahkan tingkat pemanfaatannya hampir $0 \%$. Hal tersebut karena untuk produk buah impor Indonesia dari Pakistan lebih banyak untuk produk yang tidak mendapat preferensi seperti kurma, apricot dan pisang. Sementara produk buah dalam HS 08 yang memperoleh preferensi IPPTA hanya jeruk.

\section{KESIMPULAN DAN REKOMENDASI KEBIJAKAN}

IJEPA merupakan kerja sama perdagangan bebas yang sangat komprehensif dengan cakupan liberalisasi produk pada hampir semua pos tarif dibandingkan dengan IPPTA yang hanya meliberalisasi pos tarif tertentu yang menjadi prioritas dalam perdagangan bilateral Indonesia dan Pakistan. Melihat tingkat pemanfaatannya, Indonesia belum secara optimal memaksimalkan skema IJEPA dalam ekspornya. Terdapat gap yang negatif dari pemanfaatan ekspor terhadap impor dengan tren yang terus meningkat. Hal ini akan berdampak pada neraca perdagangan bilateral di masa yang akan datang. Pemerintah perlu mengambil langkah kebijakan yang dapat mengoptimalkan pemanfaatan preferensi IJEPA untuk mendorong ekspor Indonesia ke Jepang dan memperbaiki neraca perdagangan.

Sementara itu, walaupun IPPTA merupakan kerja sama perdagangan bebas yang hanya dalam bentuk tarif preferensi untuk produk tertentu tetapi tingkat pemanfaatannya lebih tinggi di sisi Indonesia dibandingkan Pakistan. Dampak IPPTA telah mendongkrak neraca perdagangan Indonesia terhadap Pakistan. Jumlah perusahaan pengguna skema IPPTA juga masih meningkat signifikan.

Melihat hasil yang sangat berbeda dari pemanfaatan IJEPA dan IPPTA nampaknya kerja sama dalam bentuk Preferential Trade Agreement (PTA) lebih sesuai untuk Indonesia dibandingkan kerja sama dalam bentuk perjanjian perdagangan yang komprehensif seperti IJEPA. Hal tersebut karena cakupan produk yang diliberalisasi dalam PTA dipilih sedemikian sehingga merupakan produk yang menjadi prioritas utama dalam meningkatkan perdagangan di 
negara mitra FTA. Sementara itu IJEPA mencakup hampir seluruh produk yang diperdagangkan sehingga produkproduk yang tidak memiliki daya saing juga harus berkompetisi dengan produk yang berasal dari Jepang.

Rekomendasi yang diberikan berdasarkan hasil studi adalah kerja sama perdagangan Indonesia dalam kerangka bilateral sebaiknya dilakukan dalam bentuk kerja sama preferensi pengurangan tarif atau Preferential Trade Agreement (PTA) untuk produk yang menjadi unggulan Indonesia. Kerja sama PTA terbukti dapat mendorong ekspor dan tingkat pemanfaatan yang lebih tinggi dibandingkan FTA yang lebih komprehensif. Pembentukan kerja sama Economic Partnership seperti IJEPA perlu disertakan pula kerja sama yang menjamin peningkatan perdagangan dan pemanfaatan preferensi yang seimbang antara negara anggota. Pemerintah juga perlu mendorong para pelaku usaha dalam memanfaatkan FTA Indonesia yang sudah ada agar lebih optimal.

\section{UCAPAN TERIMA KASIH}

Penulis mengucapkan terima kasih kepada Ibu Kepala Pusat Pengkajian Kerja sama Perdagangan Internasional yang telah mengijinkan penulis untuk menyusun kajian ini dalam Buletin Ilmiah Litbang Perdagangan. Penulis juga menyampaikan terima kasih kepada tim Puska KPI: Deky Paryadi, dan Wibowo Kurniawan atas kontribusinya dalam penulisan kajian Pemanfaatan Perundingan Perdagangan Internasional Indonesia. Penulis juga mengucapkan terima kasih kepada Dr. Risna Triandhari, SE, M.SE atas masukannya dalam penyusunan studi ini.

\section{DAFTAR PUSTAKA}

Ando, M. Kimura, F. (2012). How Did the Japanese Exports Respond to Two Crises in the International Production Network?: The Global Financial Crisis and the East Japan Earthquake. ASEAN Economic Journal, Volume 26(3), Halaman 261-287

Ardiyanti, S.T. (2015). Dampak Perjanjian Perdagangan Indonesia-Jepang (IJEPA) Terhadap Kinerja Perdagangan Bilateral. Buletin IImiah Litbang perdagangan, Vol: 9(2), halaman 129-15

Athukorala, P.C. \& A. Kohpaiboon. (2011). 'Australia-Thailand Trade: Has the FTA Made a Difference?', Australia National University Working Papers in Trade and Development No. 2011/12, Canberra: ANU.

Budiarti, F.T \& Hastiadi, F.T. (2015). Analisis Dampak Indonesia Japan Economic Partnership Agreement terhadap Price-Cost Margins Industri Manufaktur Indonesia. Jurnal Ekonomi dan Pembangunan Indonesia, Vol: 15(2), Halaman 192209

Candau, O., Carrare, C., De Melo, J., \& Tumurchudur, B. (2004). The Utilization Rate of Preferences in the 
EU. Paper presented at the 7th Global Economic Analysis Conference, Washington D.C., 17-19 June 2004.

Cheong, I. (2014). Korea's Polcy Pavlage for Enhancing its FTA Utilization and Implications for Korea's Policy. Eria Discussion Paper Series ERIA-DP2014-11.

Gocklas C.S, L. Sulasmiyati, Sri. (2017). Analisis Pengaruh Indonesia-Japan Economic Partnership Agreement (IJEPA) Terhadap Nilai Perdagangan Indonesia-Jepang.

Jurnal Administrasi Bisnis (JAB), Vol: 5(5), halaman 191- 200

Hayakawa, K., Laksanapanyakul, N., \& Shiino, K. (2013a). Some Practical Guidance for the Computation of Free Trade Agreement Utilization Rates. IDE Discussion Paper No. 438.

Hayakawa, K., Laksanapanyakul, N., \& Shiino, K. (2013b). FTA Utilization: Certificate of Origin Data Versus Customs Data. Institute of Developing Economies (IDE) Discussion Paper No 428

Hayakawa, K. (2014). Impact of diagonal cumulation rule on FTA utilization: Evidence from bilateral and multilateral FTAs between Japan and Thailand. Journal of the Japanese and International Economies, Volume 32, halaman 1-16.

Hayakawa, K., Kim, Hansung., Lee, HyunHoon. (2014). Determinants on Utilization of Korea-ASEAN Free Trade Agreement: Margin Effect, Scale Effect, and ROO effect. World Trade Review, Volume 13(3), halaman 499-515.

Hayakawa, K., Laksanapanyakul, N., Urata, S. (2016). Measuring the Cost of FTA Utilization: Evidence from Transaction-Level Import Data of Thailand. Review of World Economics, Volume 152(3), Halaman 559-575.

Hayakawa, K. Laksanapanyakul, N. (2017). Impacts of Common Rules of Origin on FTA Utilization. International Economics and Economic Policy, Volume 14(1), halaman 75-90.

Inama, S. (2003). Trade Preferences and the World Trade Organization Negotiations on Market Access. Journal of World Trade, 37 (5), 959979

Ing, Lili Yan., Urata, S., Fukunaga, Y. (2016). How Do Exports and Imports Affect the Use of Free Trade Agreements? Firm-level Survey Evidence from Southeast Asia, ERIA Discussion Paper Series, ERIA-DP2016-01.

Itaravitak, C., Mudkum, C., Panpheng, K. (2011). Rules of Origin and Utilization of Free Trade Agreements: An Econometric Analysis. TDRI Quarterly Review

Kawai, M. \& G. Wignaraja. (2011). Asia's Free Trade Agreements: How is Business Responding? Cheltenham (UK): Edward Elgar.

Kawai, M., Wignaraja, G. (2013). Patterns of Free Trade Areas in Asia. East West Center, Honolulu (Hawai)

Keck, Alexander \& Lendle, Andreas. (2012). "New evidence on preference utilization," WTO Staff Working Papers ERSD-2012-12, World Trade Organization (WTO), Economic Research and Statistics Division.

Ministry of Foreign Affairs of Japan. (2018). Joint Press Statement on the Occasion of the entry into force of the Agreement between Japan and the Republic of Indonesia for an Economic Partnership. Dipetik Juni 2018 dari MOFA: https://www.mofa.go.jp/region/asiapaci/indonesia/joint0807.html

PBC. (2015). An Analysis Of The PakistanIndonesia Pta \& A Framework For Negotiating The Pakistan-Indonesia FTA.

Okabe, Misa. (2015). 'Impact of Free Trade Agreements on Trade in East Asia', 
ERIA Discussion paper Series, ERIADP-2015-01

Ratananarumitsorn, T., T. Piyanirun, \& Laksanapanyakul. (2008). " Utilization of Free Trade Agreement Preferences: The Case of Thai Agricultural Export", TDRI Quarterly Review (September), pp. 11-18

Setiawan, S. (2012). Analisis Dampak IJEPA Terhadap Indonesia dan Jepang. Jurnal Ilmiah Ekonomi dan Bisnis, Vol: 17(2).

Sitepu, E.M.P., Nurhidayat, R. (2015). Mengukur Tingkat Pemanfaatan FTA yang telah dilakukan Indonesia: Studi Kasus dengan Menggunakan FTA Preferences Indicator. Kajian Ekonomi dan Keuangan, Volume 19, No.3 halaman 284-298.
Takahashi, K., \& Urata, S. (2008). On the use of FTAs by Japanese firms (Discussion Paper No. 08-E-002). Tokyo: Research Institute of Economy, Trade, and Industry.

Takahashi, K., \& Urata, S. (2009). On the use of FTAs by Japanese firms: Further Evidence. Discussion Paper Series No. 09-E-028. Tokyo: Research Institute of Economy, Trade, and Industry.

Wignaraja, G. Lazaro, D. De Guzman, Genevieve. (2009). Factrors Affecting Use or Nonuse of Free Trade Agreements in the Philipines. Philipines Journal of Development, Vol: 36(2), halaman 69-95. 
